Journal of

International Logistics and Trade

\title{
The Impact of Logistics Efficiency and Free Trade Agreements on Global Trade: Focusing on Total Trade Value
}

\author{
Kyong Han Lee ${ }^{\mathrm{a}, \mathrm{b}}$, Sang-Yoon Lee ${ }^{\mathrm{c} *}$ \\ ${ }^{a}$ Korea Maritime Institute, Busan, Korea \\ ${ }^{\mathrm{b}}$ Graduate School of Logistics, Inha University, Incheon, Korea \\ ${ }^{\mathrm{c}}$ Asia Pacific School of Logistics, Inha University, Incheon, Korea
}

\begin{abstract}
ARTICLE INFO
Article history:

Received 25 November 2016

Accepted 7 December 2016

Keywords:

Trade facilitation

Logistics efficiency

Free trade agreement

Bilateral trade

Multilateral trade

Trade value

ABSTRACT

The purpose of this study is to empirically analyze the impact of logistics efficiency on trade volume growth, and to examine the effects of lower tariffs resulting from free trade agreements. In order to measure the impact of logistics efficiency on trade volume growth, the export and import trade volume among 53 countries was introduced as the dependent variable. Macroeconomic indicators including annual average tariff rate, logistics efficiency indicators for port, air, railroad, road and container vessel connectivity, as well as dummy variables such as whether a free trade agreement was signed, were introduced as the explanatory variables. Bilateral panel data between trading nations was used to estimate the gravity panel model, and analysis followed the categorization: 1) separate inputs of the five logistics efficiency variables and 2) one aggregated input of the five variables as a single indicator. The analysis found that logistics efficiency had a statistically significant impact on bilateral trade volume growth, while the impact of lowering tariff rates on increasing trade was insignificant. In addition, logistics efficiency was found to have a greater impact on increasing trade volume than free trade agreements. These results imply that trade can be promoted more effectively by establishing and efficiently operating logistics-related infrastructure rather than traditional methods of reducing trade barriers such as lowering tariffs and signing free trade agreements.
\end{abstract}

\section{Introduction}

One of the most important trends in the growth of global trade is trade liberalization. The global trend of trade liberalization has made progress in two forms: WTO (World Trade Organization) and DDA (Doha Development Agenda), which involve multilateral trade agreements, and free trade agreements (FTA), which are bilateral trade agreements. In order to reduce trade costs, many countries have signed bilateral FTAs, and recently, discussions on mega-FTAs are ongoing. However, while tariffs have lowered under the WTO system, differences in customs clearance procedures between countries, as well as complexity and opacity of customs systems, such as document requirements, still persist. In particular, it is estimated that the costs incurred by delay in movement of goods across borders, complex and unnecessary document requests, and lack of automation in trade procedures exceed tariff costs (Choi et al. 2015). Recently, with the growth in e-commerce, such as overseas direct purchase, has increased dramatically and in order to support the timeliness in manufacturing and logistics of the private sector, there has been increased attention focusing on trade facilitation.

While the meaning and scope differs by trade organizations and institutions promoting economic cooperation, trade facilitation encompasses measures expanding trade through lowering costs and promoting efficiency by simplifying

\footnotetext{
* Corresponding author: Asia Pacific School of Logistics, Inha University, 100 Inha-ro, Nam-gu, Incheon, 22212, Korea

Email: sylee@inha.ac.kr
} 
unnecessary and complex procedures, practices, and infrastructure. Trade facilitation goes beyond the boundaries of non-tariff barriers, which includes import licenses, customs valuation, rules of origin, and technical barriers to trade, and further aims to reduce trade costs and promote trade. This is achieved by simplifying, automating, and standardizing inefficient systems and trade flows throughout all global trade processes, including exports-import procedures, standard/conformity assessment, transport and financial conditions, and cross-border movements of goods (Lee 2005).

When the WTO trade facilitation agreement comes into effect, it is expected that similar effects to lowering non-tariff barriers will occur due to the simplified customs clearance procedures between member nations, and the anticipated effects may include facilitated movement of goods, increased trade, and faster customs clearance. For developing nations, with the improved customs clearance process and lower trade costs, an increase in exports is expected. According to the OECD's trade facilitation indicators, when the trade facilitation agreement comes into effect, global trade costs are expected to decrease 12.5 17.5\%. In addition, the gap of decrease in trade costs between countries that completely implement the agreement and countries that do not is estimated at 1.4 3.9\%. In particular, as the global manufacturing/logistics network of multinational corporations are becoming more sophisticated, logistics costs and logistics efficiency is receiving more attention (Ando and Kimura 2013). Therefore, trade facilitation is expected to have a strong relationship with the efficiency of the four major methods of transport: marine transport, air transport, land transport, and railroad transport.

This research will empirically examine the effects of trade facilitation measures of 53 major global trading countries on trade volume growth. Also, the impact of logistics efficiency and FTAs on trade volume growth will be compared and analyzed.

\section{Literature review}

Much of previous research has examined the effect of trade facilitation measures including logistics efficiency on global or regional trade. Hoekman and Nicita (2008) analyzed the impact of promoting trade efficiency on trade volume using the World Bank's Logistics Performance Index, and results indicated that logistics efficiency had a significant impact on trade volume growth. Shepherd and Wilson (2009) used trade facilitation indicators, such as information technology and logistics infrastructure, to study the impact of logistics on promoting trade in the ASEAN countries. Results showed that establishing infrastructure for logistics facilitation had a greater impact on increasing trade volume than making customs clearance procedures more efficient. Dennis and Shepherd (2011) considered costs of domestic market barriers and export barriers to study the trade facilitation effects in 118 developing nations. Improvement in customs procedures was suggested as the major factor of trade facilitation, and resulted in increased exports and greater diversification of exports. Serhat and Harun (2011) claimed that logistics infrastructure, such as roads, ports, and airports, has a significant impact on global trade, and that trade efficiency promotes trade competitiveness and economic growth of the nation as well as industry efficiency. Li and Qi (2016) proposed a logistic connectivity model to examine the relationship between transport connectivity and regional economic development in China. By focusing on 31 provinces and 11 variables, including new logistics factors (density of road and railway network, number of internet users), empirical results show transport connectivity has had a positive impact on economic development in China. Reza et al. (2015) analyzed which Liner Shipping Connectivity Index (LSCI) components contribute the most in improving the shipping connectivity of six South-Asian countries. Results found the country's port capacity, which can accept larger ship sizes, has the most significant impact on improved connectivity in the region.

In addition, research has utilized the gravity model to analyze the effects of trade facilitation measures and FTAs on trade volume growth. Frankel et al. (1996) used the gravity model to analyze significant factors that affect a nation's trade volume. Trade volume was the dependent variable, distance, inland area, and population were major explanatory variables, and whether regional economic agreements were signed, such as APEC or NAFTA, was the dummy variable. Coughlin and Wall (2003) used the gravity model to analyze regional export growth of the NAFTA member nations, and the United States was estimated to have approximately a 15\% increase in exports. Sharma and Chua (2010) utilized the gravity model to analyze the trade pattern changes among 5 ASEAN nations from 1980-1995 and found that the signing of FTAs among nations in the ASEAN region did not affect the increase in regional trade, though the trade volume with APEC member countries increased slightly.

Kim (2010) analyzed the impact that the FTA between Korea and EU would have on trade. Signing the FTA between the two parties was identified to have positive effects on Korean exports to Europe. In order to identify factors that affect the total quantity of import containers used for trade between Busan port and Chile, Nam et al. (2013) used the gravity model for analysis. Results found GDP and tariff rates had statistically significant effects on the increase and decrease of the total quantity of import containers transported from Busan port to Chile, but the ocean freight charge had markedly low statistical significance and coefficient consistency.

Park and Kim (2014) estimated the export effects of signing the FTA on the quantity of goods transported in Gwangyang Port. An analytic result in which population, the distance between trading partners, freight charges, and cultural factors were considered as the explanatory variables showed that signing the FTA had a positive effect on the 
exports in Gwangyang Port, and the greater the distance and freight charges, the lower the export volume.

Kim et al. (2015) used the gravity model to estimate changes in trade patterns of air cargo resulting from environmental factors in global trade. The subject of analysis was the amount of air cargo between Korea and trading nations, and variables included FTA and economic integration variable, income level, market size, and distance between the two countries. Results found that the FTA and economic integration variable had a positive impact on air cargo trade. Park et al. (2016) used the gravity model on the container export volume of Korea's major ports of Busan, Inchon, and Gwangyang, in order to analyze the pattern of marine trade changes. Inchon port experienced trade creation effects with ASEAN+3 and NAFTA member nations, and Gwangyang port showed a positive correlation in trade with NAFTA member nations. Meanwhile, Lee (2015) used the gravity model with bilateral trade data set of 34 OECD countries to examine the effects of culture proximity and networks on international trade. Results found that among network variables, the internet had the strongest interaction effect followed by FDI and migration. Variables such as FDI, migration and internet plays an important role in reducing the deterrent effects of cultural differences on international trade.

\section{Research model and data collection}

\subsection{Research model}

The basic model used for empirical analysis in this research is the gravity model. The gravity model applies Newton's Universal Law of Gravitational Attraction on international trade theory, and considers remoteness level between countries and social/cultural elements. Gravitational attraction, a physics term, is based on the theory that gravity between two objects is proportional to their masses and is inversely proportional to the distance between them. The universal law of gravitational attraction can be expressed in the following equation (1):

$$
F_{i j}=\sigma \frac{M_{i} M_{j}}{D_{i j}^{2}},(i \neq j)
$$

In equation (1), $F_{i j}$ refers to the gravitational attraction between the two objects, $M_{i}$ and $M_{j}$ are the masses of the two objects, $D_{i j}$ is the distance between the two objects, and $\sigma$ is the gravitational constant. The basic premise of such a gravity model is that the trade volume is proportionate to the square of GDPs of the two countries and inversely proportionate to the distance between the trading nations (Deardorff 1998). The basic equation that applies the universal law of gravitational attraction on the gravity model can be expressed as:

$$
T_{i j}=A \frac{Y_{i} Y_{j}}{D_{i j}},(i \neq j)
$$

In equation (2), $T_{i j}$ is the trade volume between country $i$ and its trading nation $j ; Y_{i}$ is country $i$ 's GDP; $Y_{j}$ is trading nation $j$ 's GDP; $D_{i j}$ is the distance between the two countries; and $A$ is the proportional constant. In this equation, independent variables representing a nation's economic size and trade volume can be added, such as population, per capita GDP, total area of the nation's land and sociocultural elements, including whether the country was colonized in the past, whether a common language is used, whether the countries share borders, and whether nations belong to FTAs can also be added. For example, when natural logarithms are added on both sides of equation (2), the basic equation of the gravity model used in past studies is as follows:

$$
\ln \left(T R A D E_{i j}\right)=\beta_{1}+\beta_{2} \ln \left(G D P_{i} G D P_{j}\right)+\beta_{3} \ln \left(P O P_{i} P O P_{j}\right)+\beta_{4} \ln \left(D I S T_{i j}\right)+\beta_{5} F T A_{i j}+\varepsilon_{i j}
$$

In equation (3), GDP and POP are variables that show the economic size of nation $i$ and nation $j$, DIST represents the distance between the two countries, and FTA is the dummy variable whether the FTA has been implemented. The expected coefficient value of the trade pattern is $\beta_{2}>0, \beta_{3}>0, \beta_{4}<0, \beta_{5}>0$.

\subsection{Basic data}

The spatial scope of this empirical study includes 53 countries with data for the explanatory variables in the gravity model available from 2006-2015. The trade volume, which is the dependent variable, was collected through Data Insight of Global Insight. 
Table 1. Descriptive statistics by data

\begin{tabular}{|c|c|c|c|c|}
\hline $\begin{array}{ll} & \text { Statistics } \\
\text { Variable } & \end{array}$ & Average & Standard deviation & Minimum value & Maximum value \\
\hline $\ln (T R A D E)$ & 14.0 & 2.2 & 1.6 & 20.2 \\
\hline $\ln (G D P)$ & 53.6 & 1.8 & 48.2 & 60.5 \\
\hline $\ln (P O P)$ & 34.5 & 2.0 & 29.8 & 42.0 \\
\hline $\ln (D I S T)$ & 8.5 & 1.0 & 4.1 & 9.9 \\
\hline$C O L$ & 0.0 & 0.2 & 0.0 & 1.0 \\
\hline COMCOL & 0.0 & 0.1 & 0.0 & 1.0 \\
\hline$L A N G$ & 0.1 & 0.3 & 0.0 & 1.0 \\
\hline CONTIG & 0.0 & 0.2 & 0.0 & 1.0 \\
\hline$F T A$ & 0.1 & 0.3 & 0.0 & 1.0 \\
\hline $\ln (T A R F)$ & 0.7 & 1.7 & -4.5 & 3.1 \\
\hline $\ln (A I R)$ & 1.6 & 0.2 & 1.0 & 1.9 \\
\hline $\ln (R O A D)$ & 1.4 & 0.3 & 0.6 & 1.9 \\
\hline $\ln (P O R T)$ & 1.5 & 0.3 & 0.8 & 1.9 \\
\hline $\ln (R A I L)$ & 1.3 & 0.4 & 0.0 & 1.9 \\
\hline $\ln (C C I)$ & 3.2 & 1.3 & 0.0 & 5.1 \\
\hline $\ln (L P)$ & 1.8 & 0.4 & 1.0 & 2.5 \\
\hline
\end{tabular}

Note: Statistics are used by panel data and observation numbers are 633,862.

Source: IMF, World Bank, WTO, KITA, SP-IDC.

The GDP and POP data for each nation was collected using the World Bank's Open Data, and the distance between the two nations (DIST) was collected from the Great Circle Distances between Capital Cities website. Data regarding $C O L$, which represents whether the country was previously colonized by its trading nation, COMCOL, which represents that both trading nations had the past experience of being colonized, $L A N G$, which measures whether the two countries share the same official language, CONTIG, which determines whether the two nations share borders, was acquired from CEPII (Centre d'Etudes Prospectives et d'Informations Internationales). The FTA variable, which means that the FTA between the two nations is in effect, is based on WTO data. Also, the container maritime connectivity indices $C C I_{i}$ and $C C I_{j}$, which were considered as the logistics efficiency variable, were collected from World Bank's data. The annual average tariff rate for each nation $\left(T A R F_{i}, T A R F_{j}\right)$ and the other four indicators of logistics efficiency: air efficiency indicator $\left(A I R_{i}, A I R_{j}\right)$, road efficiency indicator $\left(R O A D_{i}, R O A D_{j}\right)$, railroad efficiency indicator $\left(R A I L_{i}, R A I L_{j}\right)$ and port efficiency indicator $\left(P O R T_{i}, P O R T_{j}\right)$ - were collected from the annual statistical data provided by the World Economic Forum. The descriptive characteristics of data are shown in Table 1 above.

\section{Empirical analysis process and model specification}

\subsection{Analysis process}

Empirical analysis in this study was conducted as following steps: First, homoscedasticity of the error term is checked using the ordinary least square method (OLS). Then considering cases where the panel data does not satisfy that condition, the generalized least square method is performed. Lastly, after estimating the constraint model (model that doesn't consider heteroscedasticity) and non-constraint model (model that considers heteroscedasticity), based on the log-likelihood estimates deduced from the two models, the Hausman test is conducted.

In this study, the gravity model and panel analysis method is used for analyzing the effects of logistics efficiency, macroeconomic indicators, whether the countries are members of an FTA, each country's population and geographic/cultural elements, on bilateral trade volume in 53 countries. There are five logistics efficiency indicators applied to empirical analysis: airport efficiency, port efficiency, road efficiency, railroad efficiency, and container maritime connectivity indicator.

Many previous studies have employed the combined data of logistics efficiency variables to analyze the effect of logistics efficiency on bilateral trade. For example, Bang (2009) used the Logistics Performance Index by the World Bank as the logistics efficiency variable in order to analyze the effects of promoting logistics efficiency in the East Asia region on trade volume. Also, Iwanow and Kirkpatrick (2009) calculated the arithmetic mean of port, airport, railroad, and road efficiency variables and considered the single combined indicator in order to analyze the effects of developing nations' hard infrastructure efficiency on exports. In this study, logistics efficiency variable was constituted in two distinct ways: one was to analyze with a combined logistics efficiency variable consistent with previous research, and the other was to consider each indicator simultaneously to estimate the effect of individual hard infrastructure variables on trade growth. 


\subsection{Research model 1: analyzing the combined effect of logistics efficiency}

By calculating the logistics performance index for each country, which is the arithmetic mean of the five indicators of airport efficiency, port efficiency, road efficiency, railroad efficiency, and container vessel connectivity index, the effects of logistics efficiency on trade volume growth was analyzed. The regression equation is as follows:

$$
\begin{aligned}
\ln \left(T R A D E_{i j t}\right) & =\beta_{1}+\beta_{2} \ln \left(G D P_{i t} G D P_{j t}\right)+\beta_{3} \ln \left(P O P_{i t} P O P_{j t}\right)+\beta_{4} \ln \left(D I S T_{i j}\right)+\beta_{5}\left(C O L_{i j}\right)+\beta_{6}\left(C O M C O L_{i j}\right)+\beta_{7}\left(L A N G_{i j}\right) \\
& +\beta_{8}\left(C O N T I G_{i j}\right)+\beta_{9}\left(F T A_{i j}\right)+\beta_{10} \ln \left(T A R F_{i t}\right)+\beta_{11} \ln \left(T A R F_{j t}\right)+\beta_{12} \ln \left(L P_{i t}\right)+\beta_{13} \ln \left(L P_{j t}\right)+\varepsilon_{i j t}
\end{aligned}
$$

$\begin{array}{ll}T R A D E_{i j t} & \text { The trade volume of country } j \text { and country } i \text { in year } t \\ G D P_{i t} G D P_{j t} & \text { The square of GDP of country } j \text { and country } i \text { in year } t \\ P O P_{i t} P O P_{j t} & \text { The square of population of country } j \text { and country } i \text { in year } t \\ D I S T_{i j} & \text { The distance between country } j \text { and country } i \\ C O L_{i j} & \text { Whether one country - country } j \text { or country } i \text { - has experience of being colonized } \\ C O M C O L_{i j} & \text { Whether both country } j \text { and country } i \text { have experience of being colonized } \\ L A N G_{i j} & \text { Whether country } j \text { and country } i \text { have a common official language } \\ C O N T I G_{i j} & \text { Whether country } j \text { and country } i \text { share borders } \\ F T A_{i j} & \text { Whether the FTA between country } j \text { and country } i \text { in year } t \text { is in effect } \\ T A R F_{i}, T A R F_{j} & \text { The average tariff rate of country } i \text { and country } j \text { in year } t \\ L P_{i}, L P_{j} & \text { The combined index of logistics efficiency of country } j \text { and country } i \text { in year } t \\ \varepsilon_{i j t} & \text { Error term }\end{array}$

\subsection{Research model 2: analyzing individual effects of logistics efficiency}

The basic model for analyzing the effects of individual logistics efficiency indicators by country on trade volume is as follows:

$$
\begin{aligned}
\ln \left(T R A D E_{i j t}\right) & =\beta_{1}+\beta_{2} \ln \left(G D P_{i t} G D P_{j t}\right)+\beta_{3} \ln \left(P O P_{i t} P O P_{j t}\right)+\beta_{4} \ln \left(D I S T_{i j}\right)+\beta_{5}\left(C O L_{i j}\right)+\beta_{6}\left(C O M C O L_{i j}\right)+\beta_{7}\left(L A N G_{i j}\right) \\
& +\beta_{8}\left(C O N T I G_{i j}\right)+\beta_{9}\left(F T A_{i j}\right)+\beta_{10} \ln \left(T A R F_{i t}\right)+\beta_{11} \ln \left(T A R F_{j t}\right)+\beta_{12} \ln \left(I N F R A_{i k t}\right)+\beta_{13} \ln \left(I N F R A_{j k t}\right) \\
& +\varepsilon_{i j t}
\end{aligned}
$$

$I N F R A_{i k t}, I N F R A_{j k t} \quad$ The efficiency indicator, $k$, of country $j$ and country $i$ in year $t(k=1$ : airport efficiency, $k=2$ : port efficiency, $k=3$ : road efficiency, $k=4$ : railroad efficiency, $k=5$ : container connectivity)

\section{Empirical analysis results}

\subsection{Research model 1: analyzing combined effects of logistics efficiency}

In order to analyze the combined effects of logistics efficiency on trade volume growth, panel analysis was performed using bilateral trade volume data from the subject countries. After comparing the fixed effects model and random effects model results of panel analysis, the Hausman evaluation was conducted in order to choose an appropriate model for analyzing total trade volume. As a result of the Hausman evaluation, the evaluation statistics was $3,020.22$, and the $\mathrm{P}$ value was less than $0.001 \%$, dismissing the null hypothesis that there is no correlation between the explanatory variable and disturbance variable, and therefore proving the fixed effect model to be appropriate.

Results of the fixed effect model analysis found the GDP of 0.780 and the POP of 0.066 at the $1 \%$ significance level. The distance between trading nations, or DIST, showed -0.888 at the $1 \%$ significance level, and it was found that the trade volume decreased by approximately $0.9 \%$ for a $1 \%$ increase in distance between countries. The variable that indicates one of the two countries' experience of being colonized $(C O L)$, the variable that indicates that the two countries use the same official language $(L A N G)$, and the variable that indicates the two countries share borders (CONTIG) all showed a statistically significant positive coefficient at the $1 \%$ significance level. In comparison, the variable that indicates both countries experience being colonized (COMCOL) was found to be statistically insignificant. Among the trade agreement variables, FTA, which is the variable that indicates whether there is an FTA between the two countries, was significant at the $1 \%$ significance level, and there was approximately $0.4 \%$ trade growth between the two nations with an effective FTA. The TARF variable, which indicates the nation's average tariff rate, was analyzed to be a statistically insignificant indicator in relation to trade volume growth in both the nation and its trading partner.

This is presumed to be due to not only the relatively low tariff rates created from bilateral FTAs and multilateral 
trade agreements but also trade barriers that became relatively higher in logistics facilitation levels such as logistics infrastructure, efficiency, and costs. LP, the combined logistics efficiency index, was statistically significant at the $1 \%$ level, and both the country and its trading partner showed positive coefficients of 0.682 and 0.675 , respectively.

Table 2. Analysis results of trade value growth effect by country (combined effect of logistics efficiency)

\begin{tabular}{|c|c|c|}
\hline Variable Analysis & Fixed effect model & Random effect model \\
\hline $\ln (G D P)$ & $0.780^{* * * *}$ & $0.649^{* * * *}$ \\
\hline $\ln (P O P)$ & $0.066^{* * *}$ & $0.128^{* * * *}$ \\
\hline $\ln (D I S T)$ & $-0.888^{* * *}$ & $-0.824^{* * * *}$ \\
\hline$C O L$ & $0.126^{* * *}$ & $0.382^{* * * *}$ \\
\hline COMCOL & 0.011 & $0.395^{* * * *}$ \\
\hline$L A N G$ & $0.274^{* * *}$ & $0.231^{* * * *}$ \\
\hline CONTIG & $0.612^{* * *}$ & $0.701^{* * * *}$ \\
\hline$F T A$ & $0.449^{* * *}$ & $0.174^{* * * *}$ \\
\hline $\ln \left(T A R F_{i}\right)$ & -0.001 & $0.008^{* * * *}$ \\
\hline $\ln \left(T A R F_{j}\right)$ & -0.006 & $0.007^{* * *}$ \\
\hline $\ln \left(L P_{i}\right)$ & $0.682^{* * * *}$ & $0.528^{* * * *}$ \\
\hline $\ln \left(L P_{j}\right)$ & $0.675^{* * *}$ & $0.528^{\text {**** }}$ \\
\hline _cons & $-25.148^{* * * *}$ & $-20.109^{* * *}$ \\
\hline Hausman test & \multicolumn{2}{|c|}{$3020.22(p<0.001)$} \\
\hline
\end{tabular}

Note: The suggested numbers are standardized regression coefficients.

$* * *, * *$, and $*$ are statistically significant in $1 \%, 5 \%, 10 \%$ level, respectively

Table 3. Analysis results of growth in trade value by country (individual effects of logistics efficiency)

\begin{tabular}{|c|c|c|c|c|c|c|}
\hline Variable Analysis & Case 1 & Case 2 & Case 3 & Case 4 & Case 5 & Case 6 \\
\hline $\ln (G D P)$ & $0.780^{* * * *}$ & $0.781^{* * *}$ & $0.799^{* * * *}$ & $0.773^{\text {*** }}$ & $0.757^{\text {*** }}$ & $0.882^{\text {**** }}$ \\
\hline $\ln (P O P)$ & $0.066^{* * *}$ & $0.142^{* * *}$ & $0.123^{* * *}$ & $0.152^{* * *}$ & $0.122^{* * *}$ & -0.002 \\
\hline $\ln (D I S T)$ & $-0.888^{* * *}$ & $-0.882^{* * *}$ & $-0.878^{* * * *}$ & $-0.863^{* * *}$ & $-0.774^{* * *}$ & $-0.901^{* * *}$ \\
\hline$C O L$ & $0.126^{* * * *}$ & $0.152^{* * *}$ & $0.160^{* * *}$ & $0.154^{* * *}$ & $0.134^{* * *}$ & $0.162^{* * *}$ \\
\hline COMCOL & 0.011 & 0.021 & 0.103 & 0.028 & 0.000 & $0.208^{\text {**** }}$ \\
\hline$L A N G$ & $0.274^{* * *}$ & $0.221^{* * * *}$ & $0.258^{* * *}$ & $0.259^{* * *}$ & $0.383^{* * *}$ & $0.280^{* * * *}$ \\
\hline CONTIG & $0.612^{* * *}$ & $0.600^{* * *}$ & $0.556^{* * *}$ & $0.606^{* * *}$ & $0.661^{* * *}$ & $0.528^{* * *}$ \\
\hline FTA & $0.449^{* * *}$ & $0.426^{* * *}$ & $0.410^{* * *}$ & $0.442^{* * *}$ & $0.517^{* * *}$ & $0.461^{* * *}$ \\
\hline $\ln \left(T A R F_{i}\right)$ & -0.001 & 0.003 & -0.002 & 0.001 & 0.004 & -0.004 \\
\hline $\ln \left(T A R F_{j}\right)$ & -0.006 & -0.002 & -0.006 & -0.004 & -0.001 & $-0.008^{*}$ \\
\hline $\ln \left(L P_{i}\right)$ & $0.682^{* * *}$ & & & & & \\
\hline $\ln \left(L P_{j}\right)$ & $0.675^{* * *}$ & & & & & \\
\hline $\ln \left(A I R_{i}\right)$ & & $1.271^{* * * *}$ & & & & \\
\hline $\ln \left(A I R_{j}\right)$ & & $1.271^{* * *}$ & & & & \\
\hline $\ln \left(R O A D_{i}\right)$ & & & $0.622^{* * *}$ & & & \\
\hline $\ln \left(R O A D_{j}\right)$ & & & $0.622^{* * *}$ & & & \\
\hline $\ln \left(P O R T_{i}\right)$ & & & & $0.998^{* * *}$ & & \\
\hline $\ln \left(P O R T_{j}\right)$ & & & & $0.994^{* * * *}$ & & \\
\hline $\ln \left(R A I L_{i}\right)$ & & & & & $0.723^{* * *}$ & \\
\hline $\ln \left(R A I L_{j}\right)$ & & & & & $0.727^{* * *}$ & \\
\hline $\ln \left(C C I_{i}\right)$ & & & & & & $0.104^{* * *}$ \\
\hline $\ln \left(C C I_{j}\right)$ & & & & & & $0.101^{* * * *}$ \\
\hline _cons & $-25.148^{* * * *}$ & $-29.465^{* * *}$ & $-27.539^{* * * *}$ & $-28.435^{* * *}$ & $-26.212^{* * * *}$ & $-26.346^{* * * *}$ \\
\hline
\end{tabular}

Note: The suggested numbers are standardized regression coefficients. $* * *, * *$, and $*$ are statistically significant in $1 \%, 5 \%, 10 \%$ level, respectively.

\subsection{Research model 2: analyzing individual effects of logistics efficiency}

The effect of each logistics efficiency indicator and average tariff rate on trade volume was analyzed. After analyzing bilateral panel data for each trading nation, results showed that all estimated coefficients except for COMCOL (both countries with experience being colonized) and TARF (annual average tariff rate) significantly affect bilateral trade flow. Table 3 displays the results of analyzing the effects of individual logistics efficiency variables on trade volume growth using 6 regression equations. Case 1 is the result of analyzing the combined effect of logistics efficiency performed earlier, and was included for comparison with the individual effects of logistics efficiency. Cases 2- 6 show the individual effects of logistics efficiency. Analysis results show that all cases except for Case 6, which 
considered container vessel connectivity index, COMCOL and TARF variables were not statistically significant. For TARF, a nation's annual tariff rate variable $\left(T A R F_{i}\right)$ in Case 6 was not statistically significant, and only the trading partner's annual tariff rate $\left(T A R F_{j}\right)$ showed a statistically meaningful negative relationship. A $1 \%$ increase in the tariff rate of the trading partner was found to have a $0.01 \%$ decreasing effect in the bilateral trade. The logistics efficiency indicators in Cases 2-6 were all statistically significant at the 1\% significance level, indicating impact on trade volume growth. The variable that had the highest growth effect on bilateral trade volume was airport efficiency (AIR), and when this efficiency increases by $1 \%$, there was a $1.3 \%$ growth in bilateral trade volume. Following AIR was port efficiency at $1.0 \%$, railroad efficiency at $0.7 \%$, road efficiency at $0.6 \%$, and container vessel connectivity at $0.1 \%$ of growth in trade volume.

\section{Conclusion}

The purpose of this study is to empirically analyze the effects of logistics efficiency, lowering tariff rates, and signing FTAs by country on trade volume growth. Study results find that both combined and individual indicators of logistics efficiency variables showed a statistically significant impact on trade volume growth, and empirically showed that global trade volume can grow through bilateral FTAs. However, the effects of lowering tariff rates on trade growth was insignificant. This implies that it could be realistically difficult to achieve trade growth by reducing tariff rates since tariff rates have already been greatly reduced. However, as this research did not include many developing nations, it is still early to make this conclusion.

The implications of this research are as follows: First, trade facilitation measures and the spread of FTAs can lead to further growth in global trade volume. Second, in order for a country's trade volume to grow, the logistics efficiency of its trading partner should also be considered. Third, trade facilitation efforts of each country can achieve higher trade growth than traditional measures of reducing tariff and non-tariff trade barriers. Fourth, by investing in logistics and transport infrastructure for logistics facilitation, the possibility of bilateral trade growth is enhanced. Fifth, by establishing a differentiated logistics facilitation program by trade means (i.e. air, marine, inland) and considering changes in economic structure and trade directions, trade growth can be achieved more effectively. Last but not least, if the efforts of logistics facilitation spread to developing nations that this research did not take into consideration, it is expected that global trade volume would further increase.

\section{Acknowledgement}

This work was supported by INHA University Research Grant.

\section{References}

Ando, I., Kimura, F., 2013. What are the opportunities and challenges for ASEAN? ERIA Discussion Paper Series, EPIA-DP-2013-31

Bang, H.K., 2009. Analysis on the effects of logistics efficiency on trade flows in East Asian countries. Korea Institute for International Economic Policy, Research Paper, 09-09.

Choi, B.Y., Kim, J.K., Bang, H.K., Kim, M.S., Lee, B.R., Lee, J.M., 2015. The strategic research on establishing trade facilitation general plan. Korea Institute for International Economic Policy, Research Report.

Coughlin, C.C., Wall, H.J., 2003. NAFTA and the changing pattern of state exports. Papers in Regional Science 82, 427-450.

Deardorff, A., 1998. Determinants of bilateral trade: Does gravity work in a neoclassic world? National Bureau of Economic Research, The Regionalization of the World Economy, 7-32.

Dennis, A., Shepherd B., 2011. Trade facilitation and export diversification. The World Economy 34, 101-122.

Frankel, J. A., Romer, D., Cyrus, T., 1996. Trade and growth in East Asian countries: Cause and Effect? NBER working paper 5732, 9-15.

Hoekman, B., Nicita, A., 2008. Trade policy, trade costs, and developing country trade. Policy Research Working Paper 4797, World Bank. 1,295-1,307.

Iwanow, T., Kirkpatrick, C., 2009. Trade facilitation and manufactured exports: Is Africa different? World Development 37, $1039-1050$

Kim, M.A., 2010. The effects of Korea-EFTA FTA on Korean trade. Hankuk University of Foreign Studies Institute for EU Studies 26, 49-71.

Kim, S.Y., Park, H., Jang, H.M., 2015. Analysis on the air cargo patterns according to changes in global trade environment. Korea Academy of International Business Management, 489-500.

Lee, J. H., 2015. Culture, network, and international trade. Journal of International Logistics and Trade 13, 21-31.

Lee, N.G., 2005. A study of WTO trade facilitation and its policy implication for Korea. The Journal of Korea research society for customs 6, 139-162.

Li, K.X., Qi, G., 2016. Transport connectivity and regional development in China. Journal of International Logistics and Trade 14, 
The Impact of Logistics Efficiency and Free Trade Agreements on Global Trade: Focusing on Total Trade Value

142-155.

Nam, K.C., Nam, H.S., Kang, D.W., 2013. An analysis on the impact of Korea-Chile FTA on Busan port: Focusing on the inbound container from Chile. Journal of Navigation and Port 37, 681-687.

Park, H.G., Kim, C.B., 2014. Effect of Korea-ASEAN FTA on export via Gwangyang port: Application of the panel gravity model and rolling regression. Journal of Korea Port Economic Association 30, 133-143.

Park, H., Jang, H.M., Kim, S.Y., 2016. Analysis of changes in maritime trade patterns according to the changing international trade environment: the case of major container ports in Korea. Journal of Korea Port Economic Association 32, 239-254.

Reza, M., Suthiwartnarueput, K., Pornchaiwiseskul, P., 2015. Liner shipping connectivity and international trade in maritime Southeast Asian countries. Journal of International Logistics and Trade 13, 43-74.

Serhat, B., Harun, S., 2011. Analyzing dependency between national logistics performance and competitiveness: Which logistics competence is core for national strategy? Journal of competitiveness 4, 4-22.

Sharma, S.C., Chua, S.Y., 2000. ASEAN: Economic integration and intra-regional trade. Applied Economics Letters 7, 165-169.

Shepherd, B., Wilson, J.S., 2009. Trade facilitation in ASEAN member countries: Measuring progress and assessing priorities. Journal of Asian Economics 20, 367-383. 